\title{
Roller Bottle
}

National Cancer Institute

\section{Source}

National Cancer Institute. Roller Bottle. NCI Thesaurus. Code C18010.

Bottles utilized as vessels for intermediate scale preparations of attachment-dependent cultured cells. Denoted 'roller bottles' because they are slowly rotated, or rolled, to permit homogeneous cell growth on all the available inner surface of the bottle. 